\title{
Cyclin-Dependent Kinase 10
}

National Cancer Institute

\section{Source}

National Cancer Institute. Cyclin-Dependent Kinase 10. NCI Thesaurus. Code C25841.

Cyclin-dependent kinase 10 (360 aa, $\sim 41 \mathrm{kDa}$ ) is encoded by the human CDK10 gene. This protein plays a role in cell cycle regulation and protein phosphorylation. 